$<$ Back to results | 1 of 1

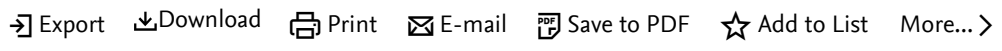

Full Text |View at Publisher|

Document type

Conference Paper

\section{Source type}

Book Series

ISSN

23673370

ISBN

978-303069220-9

DOI

10.1007/978-3-030-69221-6_48

\section{Publisher}

Springer Science and Business Media Deutschland $\mathrm{GmbH}$

Original language

English

Volume Editors

Alareeni B., Hamdan A., Elgedawy I.

View less $\wedge$

Lecture Notes in Networks and Systems • Open Access • Volume 194 LNNS, Pages 629 - 644 • 2021 • International Conference on Business and Technology, ICBT 2020, Istanbul, 14 November 2020 - 15 November 2020, 256389

Drop Shipping in the Supply Chain: Figh Perspective

Busari S.A. ${ }^{a} \nabla, \quad$ Aminu S.O. ${ }^{b}$, Zakariyyah $\mathrm{H}^{\mathrm{b}}{ }^{\mathrm{B}} \mathrm{\nabla}$

国 Save all to author list

${ }^{a}$ Figh and Usul Figh Department, IRKHS, International Islamic University Malaysia, Kuala Lumpur, Malaysia

b IIUM Institute of Islamic Banking and Finance, Kuala Lumpur, Malaysia

Views count?

View all metrics>

\section{Cited by 0 documents}

Inform me when this document is cited in Scopus:

Set citation alert >

\section{Related documents \\ Impact of stockout compensation in e- commerce drop-shipping supply chain Kamalapur, R. , Lyth, D. \\ (2020) Operations and Supply Chain Management}

Drop-shipping in retailer-oriented dual-channel supply chain based on customer channel preferences

Yu, S. , Deng, M.-R.

(2013) International Asia Conference on Industrial Engineering and

Management Innovation: Core Areas of Industrial Engineering, IEMI 2012

Proceedings

E-commerce, as a Modulating Possibility for Application of the Dropshipping Model

Dimitrov, I. , Koprinkova-Noncheva, N. (2020) 3rd International Conference on High Technology for Sustainable Development, HiTech 2020 -

Proceedings

View all related documents based on references

Find more related documents in Scopus based on:

Authors > Keywords >

Abstract

Author keywords

Reaxys Chemistry database information

SciVal Topics

Metrics

Abstract

Drop shipping entails movement of goods where a dropshipper as entity A, sells goods that are physically stocked with entity B on a retail basis to a consumer using the online networking system. In Shari'ah, the permissibility of such business arrangement revolves around a fundamental concept of not selling what you do not own. There also exist information asymmetry between the parties where only the retailer merchant has more information than both the seller and the customer. Given its prevalence and increase patronage by Muslims, this study examined the permissibility of the dropshipping using juristic adaptation (Takyif Fiqh ) to ascertain the Shariah compliance of the existing model. Analysis of the Shariah compliant issues in the transaction cycle show that the existing dropshipping model is not fully compliant with the Shariah. Thus, alternative Shari'ah compliant contract in Wakālah, Salam and Parallel Salam are proposed to validate the dropshipping model for entrepreneurs who opt for Shari'ah compliant approach. (C) 2021, The Author(s), under exclusive license to Springer Nature Switzerland AG.

Author keywords

Disruption; Drop shipping; Parallel Salam; Shariah compliance; Supply chain; Wakālah

Reaxys Chemistry database information (i)

Substances 
Powered byReaxys

(i)

Topic name

Islamic Banking; Islamic Financial Institutions; Sukuk

Prominence percentile

96.853 (i)

Scopus metrics

Views count (?)Last updated on 19 May 2021

Views count 2021

Views count 2012-2021

References (37)

View in search results format $>$

All Export 合Print 四-mail 崌 Save to PDF Create bibliography

1 (2015) Accounting and Auditing Organization for Islamic Financial Institutions: Shariah Standards. Cited 2 times.

Dar Manama, Bahrain

2 Abu Dawud Sulaiman bin Al-jarud Maula Al-Quraish At Tayalisi, Musnad Abi Dawud AtTayalisi, Tahqiq: Muhammad bin Abdulmuhsin At-Turki, Masr: Dar Hijr, (1999-1419H)

3 Ahsanath, M.K.

(2011) Retail Management, Marketing Specialization

pp. 1-47. University of Kerala, India

4 Al-Wakālah fī Sharīah Al-Islamiyah, 23 silsilat Isdarat Majmau Fuqahau Al-Shariah bi Amrikah

(2004) Mabna Majlis Al-Islam Al-Alami Lil Dawah Wa Al-Igasah, p. 429.

, $\mathrm{p}$

5 Al-Shboul, M.A.R., Barber, K.D., Garza-Reyes, J.A., Kumar, V., Abdi, M.R.

The effect of supply chain management practices on supply chain and manufacturing firms' performance (Open Access)

(2017) Journal of Manufacturing Technology Management, 28 (5), pp. 577-609. Cited 34

times.

http://www.emeraldinsight.com.ezlib.iium.edu.my/info/journals/jmtm/jmtm.jsp

doi: 10.1108/JMTM-11-2016-0154

View at Publisher

6 Amer Abu Taleb, $\mathrm{H}$.

The Parallel Forward-Buying (SALAM) Contract and its Role Toward the Achievement of

Economic Security. Majallah Al-arabiyah li Dirāsat Al-Amniyah wa Al-Tadrīb

(2015) Riyad, pp. 43-80.

, pp

7 Ayanso, A., Diaby, M., Nair, S.K.

Inventory rationing via drop-shipping in Internet retailing: A sensitivity analysis

(2006) European Journal of Operational Research, 171 (1), pp. 135-152. Cited 65 times. doi: 10.1016/j.ejor.2004.07.060

View at Publisher 
8 Chen, J., Chen, Y., Parlar, M., Xiao, Y.: Optimal inventory and admission policies for dropshipping retailers serving in-store and online customers. IIE Trans. 43(5), 332-347 (2011). https://doi. org/10.1080/0740817X.2010.540637

9 Choo, J., Stefano, B.

E-commerce trends and challenges: A logistics and supply chain perspective

(2016) Asia Pacific White Papers Series, p. 78.

, p. , The Logistics Institute - Asia Pacific National University of Singapore, Singapore

10 Chopra, S.

Designing the distribution network in a supply chain

(2003) Transportation Research Part E: Logistics and Transportation Review, 39 (2), pp.

123-140. Cited 216 times.

www.elsevier.com/inca/publications/store/6/0/0/2/4/4/

doi: 10.1016/S1366-5545(02)00044-3

View at Publisher

11 Chou, D.C., Tan, X., Yen, D.C.

Web technology and supply chain management

(2004) Information Management and Computer Security, 12 (4), pp. 338-349. Cited 59

times.

doi: $10.1108 / 09685220410553550$

View at Publisher

12 Ferreira, C.: What Is Dropshipping? Shopify Blog, 1 January 2021.

https://www.shopify.my/blog/what-is-dropshipping. Accessed 10 Feb 2021

13 Gan, X., Sethi, S.P., Zhou, J.

Commitment-penalty contracts in drop-shipping supply chains with asymmetric demand information

(2010) European Journal of Operational Research, 204 (3), pp. 449-462. Cited 78 times. doi: 10.1016/j.ejor.2009.11.008

View at Publisher

14 Grover, V., Ramanlal, P.

Six myths of information and markets: Information technology networks, electronic commerce, and the battle for consumer surplus

(1999) MIS Quarterly: Management Information Systems, 23 (4), pp. 465-495. Cited 120

times.

http://misg.org/misq/downloads/

doi: $10.2307 / 249486$

View at Publisher

15 Hassanain, K.M.A.

(2016) Islamic Finance and Banking. Islamic Research and Training Institute Member of the Islamic Development Bank Group Jeddah

16 Hayes, M., Youderian, A.

The Ultimate Guide to Dropshipping

(2013) Lulu.Com

17 Hittle, B., Leonard, K.M.

Decision making in advance of a supply chain crisis

(2011) Management Decision, 49 (7), pp. 1182-1193. Cited 12 times.

doi: $10.1108 / 00251741111151208$

View at Publisher 
18 Hovelaque, V., Soler, L., Hafsa, S.: Supply chain organization and e-commerce: a model to analyze store-picking, warehouse-picking and drop-shipping. 4OR 5(2), 143-144 (2007). https://doi. org/10.1007/s10288-006-0013-5

19 Majmau malik fadh

(2004) Juz 9, Pp, 1-592, p. 1425H.

20 Jahari, N.A., Al-Aidaros, A.-H.

Online dropship for business transaction in Malaysia: Views from Muslim scholars (2016) Int. J. Islam. Bus. (IJIB), l (1), pp. 13-28. Cited 5 times.

21 Bai Al-FudūlT, Majallah Adl, Wizarah Al-Adli (1999) Mamlakah Saudiyyah, 1420H, pp. 1-9.

, p https://adlm.moj.gov.sa/attach/24.pdf

22 Li, S., Lin, B.

Accessing information sharing and information quality in supply chain management

(2006) Decision Support Systems, 42 (3), pp. 1641-1656. Cited 498 times. doi: $10.1016 /$ j.dss.2006.02.011

View at Publisher

23 Mathien, L.D., Suresh, N.C.

Inventory management in an e-business environment: A simulated study (2015) World, 6 (2), pp. 229-247. Cited 5 times.

\section{Mengrui, Z.}

Ethical problems of international electronic commerce and countermeasures

(2015) Eur. J. Bus. Econ. Accountancy, 3 (3). Cited 2 times.

https://www.idpublications.org/wp-content/uploads/2015/03/ETHICAL-PROBLEMS-OFINTERNATIONAL-ELECTRONIC-COMMERCE.pdf

25 Michael, $\mathrm{C}$.

(2017) Dropshipping for Dummies: A beginner's Guide to Dropshipping https://www. volusion.com/blog/a-beginners-guide-to-drop-shipping/

26 Muhammad bin Ismā̄il Al-Bukhārī, A.A.: Sahihu Al-Bukharī. Dār ibn Al-Kathīr, Bairūt (2002)

27 Musa, H.B., Taib, M.S.B.M., Li, S.C.H., Jabar, J., Khalid, F.A.

Drop-shipping supply chain: The characteristics of SMES towards adopting it

(2016) Social Sciences (Pakistan), 11 (11), pp. 2856-2863. Cited 5 times.

$10.3923 /$ sscience.2016.2856.2863

28 Richard, L.

(2018) Dropshipping 101: The Definitive Guide to Building a Dropshipping Business In, p.

2019.

https://www.abetterlemonadestand.com/what-is-drop-shipping/ 
29 Power, D.

Supply chain management integration and implementation: A literature review

(2005) Supply Chain Management, 10 (4), pp. 252-263. Cited 381 times. doi: 10.1108/13598540510612721

View at Publisher

30 Pretorius, S.J.

(2001) Effective Supply Chain Effective Supply Chain Management in the Furniture Retail Industry

In: Acutt, R. (ed.) Pretoria

31 Musnad Abī Dāwūd Al-Ṭayālisī

(1999) Muhammad Bin Abdulmuhsin Al-Turki (Ed.) Dar Hijr, Masr

32 Victor, L.

(2018) Dropshipping Secrets Revealed: How We Grew a Dropshipping Business to $\$ 4.5$

Million

https://crazylister.com/blog/dropshipping-guide-success-story/

33 Yao, D.-Q., Kurata, H., Mukhopadhyay, S.K.

Incentives to reliable order fulfillment for an Internet drop-shipping supply chain

(2008) International Journal of Production Economics, 113 (1), pp. 324-334. Cited 31

times.

doi: 10.1016/j.ijpe.2007.09.002

View at Publisher

34 Yu, D.Z., Cheong, T., Sun, D.: Impact of supply chain power and drop-shipping on a manufacturer's optimal distribution channel strategy. Eur. J. Oper. Res. 259(2), 554-563 (2017). https://doi. org/10.1016/j.ejor.2016.11.025

35 Zając, D.

Dropshipping as logistics business model of e-commerce

(2014) Logistyka, 4, pp. 5069-5074. Cited 3 times.

36 Zorzini, C.

(2018) Dropshipping Definition: The Best Way to Setup a Drop Shipping Business Quickly https://ecommerce-platforms.com/ecommerce-selling-advice/setup-drop-shi ppingecommerce-website

37 Zuhailī, M.: Al-Qawā id Al-Fiqhiyah wa Tațbīqātuhā fĩ Al-Mazāhib Al-Arba, lst edn. Dar AlFikr, Al-Dimishqi (2006) ',

$\frown$ Busari, S.A.; Fiqh and Usul Fiqh Department, IRKHS, International Islamic University Malaysia, Kuala Lumpur, Malaysia; email:saheed@iium.edu.my

(C) Copyright 2021 Elsevier B.V., All rights reserved.

\section{About Scopus}

What is Scopus

Content coverage

Scopus blog
Language

日本語に切り替える

切换到简体中文

切換到繁體中文
Customer Service

Help

Contact us 
Copyright (C) Elsevier B.V ז. All rights reserved. Scopus ${ }^{\circledR}$ is a registered trademark of Elsevier B.V. 